\title{
New investigations of the native iron bearing volcanic rocks of Disko, central West Greenland
}

\section{Asger Ken Pedersen}

A reinvestigation of the native iron bearing rocks of northern Disko has been initiated as a follow up of new regional mapping. A variety of hypotheses as to formation have been put forward since the work of Steenstrup (1882a); a bibliography is given by B $\phi$ ggild (1953) and a recent review by Pauly (1969). In addition to examination of the nature of the deposits as such, the purpose of the new investigations is twofold.

(1) To map the native iron bearing volcanic rocks which can be used as stratigraphical marker horizons.

(2) To investigate the possible economic potential of segregations of native iron and sulphides found in these rocks.

\section{General occurrence}

The native iron bearing volcanic rocks belong to the Vaigat and the Maligat Formations of the early Tertiary West Greenland Basalt Group (Hald \& Pedersen, in press). The volcanic formations in the Disko-Nûgssuaq area form a cap on Cretaceous to early Tertiary sediments of marine, deltaic and non-marine facies, dominated by dark carbonaceous shales and sandstones (Rosenkrantz \& Pulvertaft, 1969). The native iron bearing volcanics, along with similar but iron free lavas, build up volcanic sequences composed of alternating lavas and tuffs in the otherwise monotonous plateau basalt landscape of northern and western Disko.

\section{Rock composition}

The iron bearing rocks and their iron free relatives, all contaminated by reaction with sedimentary rocks, are chemically characterised by a high normative orthopyroxene content and vary from just quartz normative basaltic to intermediate, quartz normative compositions, all markedly subalkaline. Subordinate contaminated dacites and rhyolites are confined to north-western Disko. The contaminated basic and intermediate rocks are characterised by phenocrysts of olivine \pm picotite, olivine + plagioclase, olivine + orthopyroxene, orthopyroxene alone, or orthopyroxene + plagioclase. Together with these are metal and sulphide phases and various xenocrysts and xenoliths.

The magma composition prior to sediment contamination, and prior to the natural reduction process which produced the iron, varied from sequence to sequence from just olivine or quartz normative to highly olivine normative tholeiitic basalt, and corresponded well with magma types represented by the other normal volcanic rocks of the Vaigat and Maligat Formations.

\section{Areal distribution and erupted volumes}

Native iron bearing volcanic rocks including sediment contaminated lavas and tuffs from the Nûgssuaq peninsula, were erupted over an area of about $8000 \mathrm{~km}^{2}$, and by far the largest volumes were piled up in north-western Disko. 
An estimate of the erupted volumes of sediment-contaminated rocks is of significance in terms of economic evaluation. The lower of the volcanic formations, the Vaigat Formation, consisting of predominantly picrite basalts, contains two lava sequences with native iron and two or three other contaminated but iron free sequences. Together these account for about $5 \mathrm{~km}^{3}$ of native iron bearing rock and more than $15 \mathrm{~km}^{3}$ of similar iron-free rock. The upper volcanic formation, the Maligat Formation, composed of predominantly feldsparphyric plateau basalts, contains two native iron bearing lava sequences accounting for about $45 \mathrm{~km}^{3}$ of rock with native iron and about $100 \mathrm{~km}^{3}$ without.

The continuation offshore of north-western Disko may account for a further 30 to $40 \mathrm{~km}^{3}$ of sediment-contaminated volcanic rocks. The total volume of sedimentcontaminated rocks may thus amount to $200 \mathrm{~km}^{3}$ which is equivalent to $0.5-1 \%$ of the total volume of volcanic rocks of Disko.

In addition to this, there are exposed sediment-contaminated intrusives, together with unexposed intrusives indicated by xenoliths.

\section{Composite volcanic units}

Native iron bearing composite intrusives and lavas at many localities characteristically show several stages of contamination and reduction processes within one volcanic unit.

The composite units consist of an early basaltic and a later more siliceous component. In the basaltic pulse; effective segregation of native iron and sulphide into bodies up to several centimetres in size occurred and a cumulation of the dense phases is observed. In the later, intermediate magma pulse iron and sulphides often show a dispersed distribution, and segregation of iron and sulphide into bodies more than a few millimetres in size is rare. Obviously the viscosity of the strongly contaminated rocks was so high that segregation and cumulation of the dense phases became ineffective.

Magma inhomogeneity due to varying degrees of reaction with wall rock sediments, in high level magma chambers, is considered to be responsible for the creation of the composite units. When upwelling from these chambers occurred, the order of appearance near or at the earth's surface was apparently at least in part determined by the magma viscosity.

\section{Inclusions}

The content of inclusions and xenocrysts varies much from unit to unit within the different contaminated lava sequences. Two major types are distinguished: (1) magmatic rocks; and (2) sedimentary rocks and their modified equivalents.

The magmatic rocks are medium to coarse-grained pyroxene-plagioclase rocks, mostly occurring as clinopyroxene-free norite which may contain a considerable amount of olivine. They are devoid of opaque Fe-Ti-oxides, but may contain a reddish coloured transparent spinel. The norites, which may contain graphite, sometimes form caps around xenoliths of shale, an expression of 'the quartz-norite divide' of Chinner \& Schairer (1962) and O'Hara (1968). The magmatic xenoliths are considered to be derived from sediment contaminated complexes emplaced in the sedimentary strata below the volcanic formations.

The sedimentary xenoliths are sandstone and sulphurous carbonaceous shale, varying 
in appearance from buchites with easily identifiable sedimentary structures, through well recrystallised and equilibrated buchites to glass free, coarse-grained, highly magma modified rocks. The latter include the graphite-spinel-plagioclase rock (Melson \& Switzer, 1966) which was described as anorthitfels by Törnebohm (1878).

The reaction between magma and sediments is very well displayed in model scale at magma-xenolith contacts, especially where the magma was squeezed into melt rich buchites.

\section{Origin and significance of the sulphur}

The Mesozoic to Tertiary dark shales of the Disko-Nûgssuaq area are rich in sulphur compounds which are believed to have contributed to the self-combustion of these sediments in recent times (Steenstrup, 1882b; Henderson, 1969). The equivalents to these shales, the partially melted and pyrometamorphosed buchites from the native iron bearing rocks, contain flakes of graphite and globular bodies of intergrown troilite and pyrrhotite, a 'quenched' immiscible sulphide melt. The sulphides are presumably formed from sedimentary sulphur compounds and most of the sulphur of the contaminated volcanic rocks originated from this source (Pedersen, in press).

A reaction of the type:

$$
\text { sedimentary } \mathrm{FeS}_{2}+\mathrm{Fe}^{2+} \rightarrow 2 \mathrm{FeS} \text { (melt) }
$$

has strongly depleted some buchites in iron outside the sulphide melt and led to the formation of remarkably iron poor coexisting silicate melts and cordierites. A similar reaction may also have affected some of the native iron bearing volcanic rocks.

The economic potential of the iron bearing volcanics of Disko is the subject of a study by F. Ulff-Møller (this report).

\section{Reducing environment of the contaminated rocks}

Some intermediate rocks show clearly reversely zoned orthopyroxene phenocrysts.

This indicates iron loss from the silicate melt and was probably due to entry of increasing amounts of iron into the iron metal phase under conditions of progressive reduction.

In the native iron bearing basaltic rocks, ilmenite formed near the solidus. In several iron bearing intermediate rocks, the late oxides crystallising from the magma are ilmenite and rutile or rutile alone. This is taken as an indication of near solidus crystallisation at oxygen fugacities at or possibly even below the buffer

$$
\mathrm{FeTiO}_{3} \rightleftharpoons \mathrm{Fe}(\text { metal })+1 / 2 \mathrm{O}_{2}+\mathrm{TiO}_{2}
$$

which defines the lower limit for oxygen fugacities during magmatic crystallisation in the lunar basalts (Haggerty, 1972).

Thus some of the native iron bearing volcanic rocks of Disko crystallised under extremely reducing conditions. They show similarities with extratelluric rocks such as the lunar basalts and with the even more reduced stone meteorites. 


\section{References}

Bøggild, O. B. 1953: The mineralogy of Greenland. Meddr Grønland 149,3, $442 \mathrm{pp}$.

Chinner, G. A. \& Schairer, J. F. 1962: The join $\mathrm{Ca}_{3} \mathrm{Al}_{2} \mathrm{Si}_{3} \mathrm{O}_{12}-\mathrm{Mg}_{3} \mathrm{Al}_{2} \mathrm{Si}_{3} \mathrm{O}_{12}$ and its bearing on the system $\mathrm{CaO}-\mathrm{MgO}-\mathrm{Al}_{2} \mathrm{O}_{3}-\mathrm{SiO}_{2}$ at atmospheric pressure. Am. J. Sci. 260, 611-634.

Haggerty, S. E. 1972: Apollo 14: Subsolidus reduction and compositional variations of spinels. Geochim. cosmochim. Acta, supp. 3, 1, 305-332.

Hald, N. \& Pedersen, A. K. in press: Lithostratigraphy of the early Tertiary volcanic rocks of central West Greenland. Rapp. Gronlands geol. Unders. 69, 17-24.

Henderson, G. 1969: Oil and gas prospects in the Cretaceous-Tertiary basin of West Greenland. Rapp. Gronlands geol. Unders. 22, 63 pp.

Melson, W. G. \& Switzer, G. 1966: Plagioclase-spinel-graphite xenoliths in metallic ironbearing basalts, Disko Island, Greenland. Am. Miner. 51, 664-676.

O'Hara, M. J. 1968: The bearing of phase equilibria studies in synthetic and natural systems on the origin and evolution of basic and ultrabasic rocks. Earth-Sci. Rev. 4, 69-133.

Pauly, H. 1969: White cast iron with cohenite, schreibersite and sulphides from Tertiary basalts on Disko, Greenland. Meddr. dansk geol. Foren. 19, 8-26.

Pedersen, A. K. in press: New mapping in north-western Disko, 1972. Rapp. Grønlands geol. Unders. 69, 25-32.

Rosenkrantz, A. \& Pulvertaft, T. C. R. 1969: Cretaceous-Tertiary stratigraphy and tectonics in northern West Greenland. Mem. Am. Ass. Petrol. Geol. 12, 883-898.

Steenstrup, K. J. V. 1882a: Om Forekomsten af Nikkeljern med Widmannstättenske Figurer i Basalten i Nord-Grønland. Meddr Grønland 4, 113-132.

Steenstrup, K. J. V. 1882b: Om Forekomsten af Forsteninger i de kulf $\varnothing$ rende Dannelser i Nord-Grønland. Meddr Grønland 5, 43-77.

Törnebohm, A. E. 1878: Über die eisenführende Gesteine von Oifak und Assuk in Grönland. Bih. K. svenska VetenskAkad. Handl. 4(10), 1-22.

Mineralogisk Museum, $\emptyset$ ster Voldgade 5-7, 1350 Copenhagen $K$.

\section{High temperature pyrrhotite and telluric iron mineralisations in western Disko, central West Greenland}

\section{Finn Ulff-Mфller}

The main purpose of the summer field work was to carry out a detailed investigation of the high temperature nickeliferous pyrrhotite and telluric iron mineralisation which occurs in the subvolcanic intrusions of the Hammers Dal Complex (Pedersen, this report, and in press), and to search for other occurrences with an economic evaluation in view.

The dyke-like intrusions are mainly found in gorges in the south facing slope of the E-W trending Hammers Dal, about $10 \mathrm{~km}$ from the west coast of Disko. They are exposed only in the upper $400 \mathrm{~m}$ of the Rinks Dal Member. The depth of the intrusions was thus $400-500 \mathrm{~m}$ below the palaeosurface, marked by the weakly contaminated basalts and more strongly contaminated 'andesites' of the Niaqússat Member which are 